\title{
BILE ACID CONTENT OF HUMAN SERUM. I. SERUM BILE ACIDS IN PATIENTS WITH HEPATIC DISEASE ${ }^{1}$
}

\author{
BY DANIEL RUDMAN ${ }^{2}$ AND FORREST E. KENDALL \\ (From the Columbia University Research Division, Goldwater Memorial Hospital and the \\ Department of Medicine, Columbia University, New York, N. Y.)
}

(Submitted for publication October 9, 1956; accepted December 6, 1956)

Lack of specific analytic methods has hitherto prevented exact studies of the effect of liver disease upon the concentration of bile acids in the serum. Until recently it has not been possible to measure the serum concentration of bile acids other than cholic acid. Various modifications of the Pettenkofer reaction have been employed to determine the serum concentration of cholic acid. Reports of "normal" serum cholic acid concentrations of $0.0 \mathrm{mg}$. per cent (1), $0.4 \mathrm{mg}$. per cent (2), 0.6 to $2.2 \mathrm{mg}$. per cent (3), and 3 to $6 \mathrm{mg}$. per cent (4) reflect the non-specific nature of this reaction. Several observers have agreed, however, that an accumulation of cholic acid occurs in the serum of patients with obstructive jaundice, elevations to $9 \mathrm{mg}$. per cent having been recorded (5). In acute hepatitis, serum cholic acid was less regularly elevated (5). In patients with portal cirrhosis, serum cholic açid as studied by Snell (6) and by Sherlock and Walshe (5) was generally not elevated.

The introduction of improved methods of separating and identifying the various bile acids (7-9) has stimulated a re-examination of this subject. A preliminary report from this laboratory (10) indicates that both dihydroxy and trihydroxy bile acids, largely in conjugated form, accumulate in the serum and are excreted in the urine of patients with obstructive jaundice. Only dihydroxy bile acid has been found in the serum of patients with Laennec's cirrhosis and no bile acid can be detected in the urine of these subjects.

The binding of bile acids by serum albumin has also been described (10). Carey (11) has reported differences in the ratio of dihydroxy and

1 This investigation was supported in part by a research grant, H-52, from the National Heart Institute, National Institutes of Health, Public Health Service, and by grants from the Albert and Mary Lasker Foundation and the Ames Company.

2 Fellow of the New York Heart Association. trihydroxy bile acids in the sera of patients with obstructive jaundice and hepatocellular disease.

The present report is concerned with: a) the bile acid content of the serum and urine in a selected series of 40 patients, 30 of whom had hepatic disease ; b) correlations between serum bile acid values and certain other manifestations of the hepatic disorder ; c) a consideration of the mechanisms responsible for certain differences of serum bile acid pattern in various types of hepatic disease.

\section{CLINICAL MATERIAL}

The subjects in this study were separated into five groups.

Group I: Ten persons without liver disease. Of these subjects, two were healthy volunteers; five had hypertensive vascular disease without cardiac or renal decompensation; one had idiopathic hyperlipemia and arteriosclerotic cardiovascular disease; one had diabetes mellitus with Kimmelstiel-Wilson syndrome; and one had bronchial asthma.

Group II: Thirteen patients under treatment for Laennec's cirrhosis. All reported a history of chronic alcoholism and inadequate diet, and presented the characteristic physical findings of Laennec's cirrhosis including ascites. There was considerable variation in the severity and stage of the disease.

Group III: Ten cases of hepatic disease associated with obstructive jaundice. Diagnoses in this group were as follows: post-operative bile duct stricture (one patient) ; congenital atresia of the bile duct (one patient) ; primary cholangitis (three patients); xanthomatous biliary cirrhosis (two patients); hepatic sarcoidosis (one patient); and two cases of chronic hepatitis with a pronounced component of biliary obstruction. All diagnoses were proved by operation, biopsy, or necropsy with the exception of patient No. 26 (Table I) in whom biopsy was not performed. All patients in this group had a persistent elevation of serum alkaline phosphatase and serum cholesterol.

Group IV: Five cases of chronic hepatitis, without evidence of biliary obstruction. In all these patients, the features of the chronic hepatic disease included jaundice present for periods of 1 to 22 months ; positive cephalin flocculation or zinc turbidity test; alkaline phosphatase 
TABLE I-Bile acid content of serum and urine

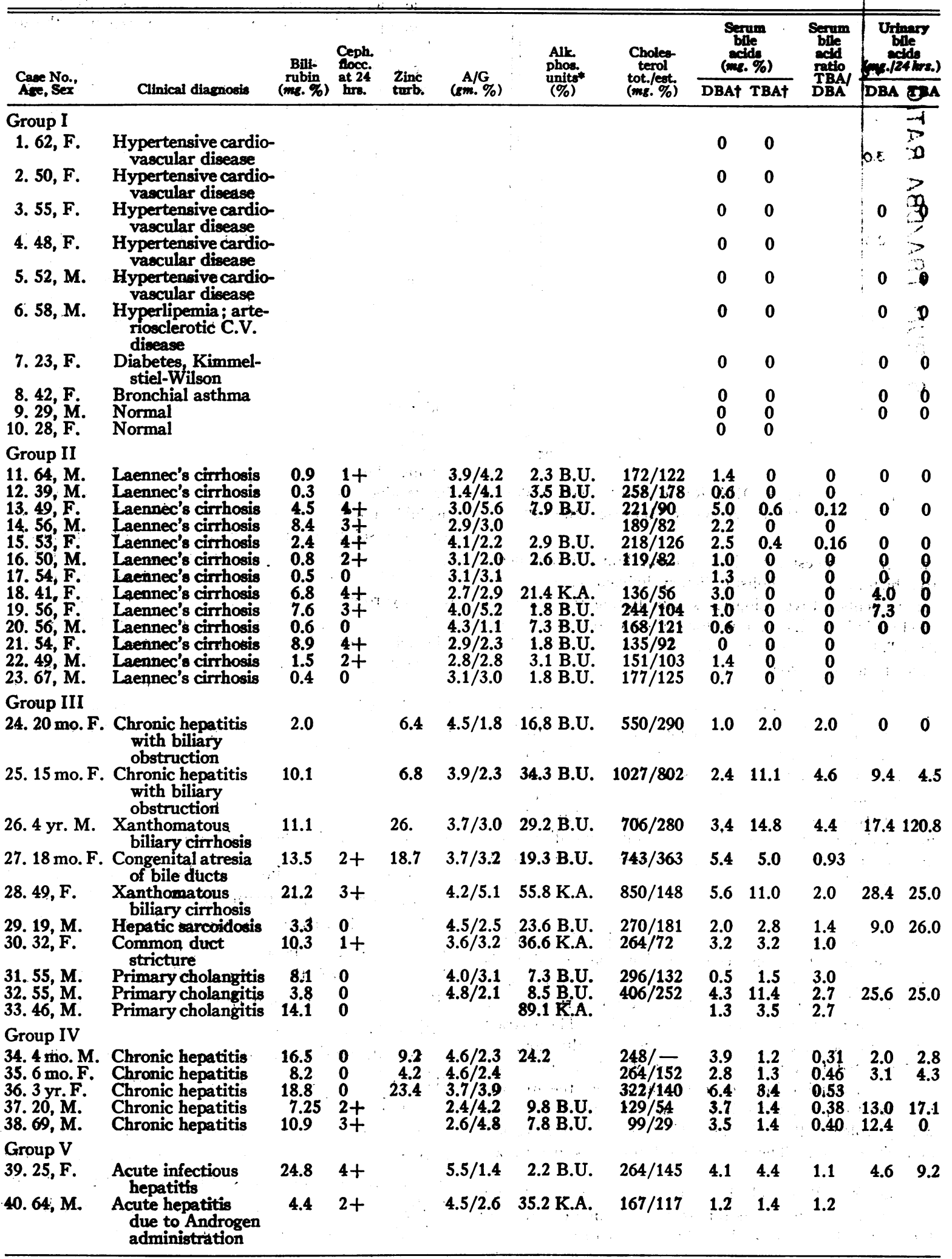

\footnotetext{
* B.U., Bodansky units; K.A., King-Armstrong units. † †BA, dihydroxy bile acid; TBA, trihydroxy bile acid.
} 


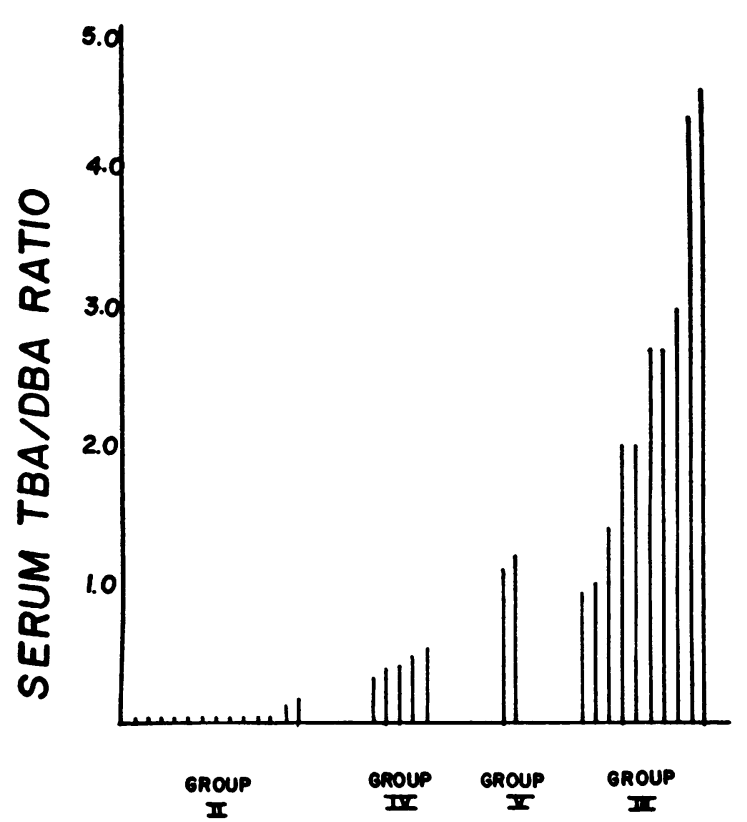

Fig. 1. Serum TBa/DBa Ratio among the Various Groups of Patients with Hepatic Disease

and serum cholesterol within normal limits; $\mathbf{8}$ and negative history for alcoholism, dietary imbalance, or hepatotoxic agents. Liver biopsies substantiating the diagnosis of chronic hepatitis were performed on Cases Nos. 34 and 35 (Table I); biopsy was not done on the other three patients in this group.

Group $V$ : Two cases of acute hepatitis. One patient was a 25-year-old woman with acute hepatitis, presumably of viral etiology, who made an uncomplicated recovery. Liver biopsy was not performed in this patient. The second subject was a 64-year-old man who became jaundiced two months after commencement of the administration of a testosterone analogue. Liver biopsy indicated acute liver cell injury. Following discontinuance of the drug, the findings of liver damage rapidly disappeared.

\section{METHODS}

Analysis was carried out on a 4 to $15-\mathrm{ml}$. sample of fresh serum. Bile acid concentration was found to be unaffected by preservation of serum for several months at $-20^{\circ}$ C. An alcoholic extract of the serum sample was made as described by Josephson (3). The extract, after removal of the barium salts and neutralization, was concentrated to a volume of about $30 \mathrm{ml}$. on the steam bath. An equal volume of $\mathrm{H}_{2} \mathrm{O}$ was added, the $\mathrm{pH}$ was adjusted to 9 , and the solution was extracted three times with petroleum ether (B.P. $68^{\circ} \mathrm{C}$ ) to remove triglycerides and cholesterol. The aqueous solution was neutralized

${ }^{8}$ Case No. 38 (Table I) in this group exhibited, during certain periods of his illness, a borderline elevation of the serum cholesterol and alkaline phosphatase. and evaporated to dryness. The bile acid content of this residue was determined by one of two procedures:

In one procedure, used for the determination of the total bile acid content, the residue was dissolved in $20 \mathrm{ml}$. 5 per cent $\mathrm{NaOH}$ and hydrolyzed by heating for 3 hours in an autoclave at $15 \mathrm{lbs}$. pressure. After cooling, the aqueous solution was made acid to Congo Red with concentrated $\mathrm{HCl}$ and extracted five times with equal volumes of ethyl ether. After being dried over $\mathrm{Na}_{2} \mathrm{SO}_{4}$ the ethereal solution was taken to dryness. The residual material was fractionated by partition chromatography according to the method of Mosbach, Zomzely, and Kendall (7). The first fraction ( 100 per cent petroleum ether) was discarded. The second and third fractions ( 60 per cent petroleum ether, 40 per cent isopropyl ether ; and 40 per cent petroleum ether, 60 per cent isopropyl ether, respectively) were taken to dryness and acetic acid was removed by repeated evaporation after the addition of benzene. Aliquots from fraction 2 were analyzed spectrophotometrically for total dihydroxy bile acid and for chenodeoxycholic acid $(7,12)$; and from fraction 3 for trihydroxy bile acid.

In the other procedure, used when information concerning the conjugation of the bile acids was desired, the residue was taken up in $50 \mathrm{ml}$. of ethanol and the insoluble portion removed by filtering. Aliquots of the ethanolic solution, after acidification, were fractionated by the reverse phase chromatographic systems of Norman (13). Appropriate fractions from the column were hydrolyzed, acidified to Congo Red, and free bile acid recovered by ether extraction. Di- and tri-hydroxy bile acids were then determined spectrophotometrically.

The bile acid content of a $50-\mathrm{ml}$. aliquot of urine was determined as follows. After the addition of $2.5 \mathrm{gm}$. of $\mathrm{NaOH}$, hydrolysis was carried out in the autoclave at 15 lbs. for 3 hours. The solution was treated thereafter exactly as described for the hydrolysate of the material derived from serum.

\section{RESULTS}

\section{Serum and urine bile acid content}

Table I gives data on the bile acid content of the serum and urine of the 40 subjects, together with other laboratory findings pertinent to the hepatic disease. Figure 1 illustrates the distribution of the serum trihydroxy/dihydroxy bile acid ratios among the four groups of patients with hepatic disease.

No bile acid could be detected in the serum or urine of any of the subjects without hepatic disease (Group I).

In 12 of 13 patients with Laennec's cirrhosis (Group II), the serum contained dihydroxy bile acid (DBA) in amounts of 0.6 to $5.0 \mathrm{mg}$. per cent. Trihydroxy bile acid (TBA) was detectable in only 2 of these cases, at a level of 0.4 and $0.6 \mathrm{mg}$. 
TABLE II

Serial bile acid determinations

\begin{tabular}{|c|c|c|c|c|c|}
\hline $\begin{array}{l}\text { Case } \\
\text { No. }\end{array}$ & Date & $\underset{m g . \%}{\text { Serum DBA }}$ & $\underset{m \varepsilon . \%}{\text { Serum TBAA }}$ & $\begin{array}{c}\text { Bilirubin } \\
\text { mg. \% }\end{array}$ & Comment \\
\hline 13 & $\begin{array}{l}7 / 28 / 55 \\
8 / 8 / 551 \\
9 / 19 / 55 \\
9 / 28 / 55 \\
10 / 11 / 55\end{array}$ & $\begin{array}{l}6.2 \\
7.2 \\
5.0 \\
5.4 \\
5.9\end{array}$ & $\begin{array}{c}0 \\
0 \\
0.6 \\
0 \\
0\end{array}$ & $\begin{array}{l}5.5 \\
5.5 \\
4.5 \\
4.7 \\
4.7\end{array}$ & $\begin{array}{l}\text { Laennec's cirrhosis } \\
\text { status quo }\end{array}$ \\
\hline 15 & $\begin{array}{l}1 / 9 / 56 \\
2 / 15 / 56 \\
3 / 12 / 56\end{array}$ & $\begin{array}{l}2.5 \\
1.7 \\
1.7\end{array}$ & $\begin{array}{c}0.4 \\
0 \\
0\end{array}$ & $\begin{array}{l}4.3 \\
2.4 \\
2.1\end{array}$ & $\begin{array}{l}\text { Laennec's cirrhosis } \\
\text { gradually receding } \\
\text { jaundice }\end{array}$ \\
\hline 38 & $\begin{array}{l}5 / 1 / 56 \\
5 / 4 / 56 \\
5 / 10 / 56\end{array}$ & $\begin{array}{l}3.0 \\
3.5 \\
5.0\end{array}$ & $\begin{array}{l}2.7 \\
1.4 \\
2.9\end{array}$ & $\begin{array}{l}10.2 \\
10.9 \\
11.6\end{array}$ & $\begin{array}{l}\text { Chronic hepatitis in } \\
\text { exacerbation; death } \\
\text { on } 5 / 26 / 56\end{array}$ \\
\hline 40 & $\begin{array}{l}8 / 26 / 55 \\
9 / 7 / 55 \\
9 / 21 / 55 \\
9 / 30 / 55\end{array}$ & $\begin{array}{l}4.1 \\
2.5 \\
1.3 \\
0\end{array}$ & $\begin{array}{l}4.4 \\
3.6 \\
0 \\
0\end{array}$ & $\begin{array}{r}24.8 \\
11.0 \\
3.2 \\
0.8\end{array}$ & $\begin{array}{l}\text { Acute viral hepatitis } \\
\text { complete recovery }\end{array}$ \\
\hline
\end{tabular}

per cent. The one subject (Case No. 21) in whom dihydroxy bile acid was not detectable in the serum was in the terminal stage of hepatic coma at the time of the analysis, following hemorrhage from esophageal varices. Urinary bile acid was determined in 8 individuals in this group. In 2 cases dihydroxy bile acid was present in the amounts of $4.0 \mathrm{mg}$., and $7.3 \mathrm{mg}$. per $24 \mathrm{hrs}$.

In all 10 cases of obstructive jaundice (Group III), the serum contained both di-and trihydroxy bile acid. TBA concentration exceeded that of DBA in 8 cases. The ratio of TBA to DBA serum concentration varied from 0.9 to 4.6 . Five of the 6 patients whose urine was analyzed, excreted both types of bile acids in the urine. The 24-hr. bile acid excretion in the adult patients varied from $9.0 \mathrm{mg}$. to $28.4 \mathrm{mg}$. for DBA; from $25.0 \mathrm{mg}$. to $26.0 \mathrm{mg}$. for TBA.

The serum of all patients with chronic hepatitis in Group IV contained both di- and trihydroxy bile acid. Dihydroxy bile acid concentration exceeded that of trihydroxy bile acid, the TBA/DBA ratio varying from 0.3 to 0.5 . Bile acids were detected in the urine in all cases studied.

In one case of acute viral hepatitis (Group V), on the 20th day of the illness the serum DBA was $4.1 \mathrm{mg}$. per cent and the TBA $4.4 \mathrm{mg}$. per cent. In a case of acute hepatic injury due to drug toxicity, serum DBA was $1.2 \mathrm{mg}$. per cent and serum TBA $1.4 \mathrm{mg}$. per cent.

\section{Serial determinations of serum bile acids}

In 4 patients the bile acid concentrations were determined repeatedly during the hospital course (Table II). There was little variation in the concentration of serum DBA in 2 patients with Laennec's cirrhosis, who exhibited little change in clinical condition during the intervals encompassed by these determinations.

On the other hand, in a man with chronic hepatitis, the serum bile acids were determined three times during an exacerbation of his disease. The serum DBA level rose steadily while the patient's condition worsened, with progressive lethargy and the onset of neurological symptoms which culminated in coma and death.

The serum of a 25-year-old woman with acute viral hepatitis was analyzed three times for bile acids during the favorable course of her illness. The decrease in serum bile acids paralleled the rapid clinical improvement.

\section{Observations on the structure of the serum bile acids}

Since the foregoing analyses of hydrolyzed extracts of serum provided no information concerning the state of conjugation, or mode of transport, of the serum bile acids; and since these details are crucial in the consideration of the mechanisms which underly the presence of bile acids in the 
TABLE III

Conjugated bile acid content of serum

\begin{tabular}{|c|c|c|c|c|c|c|}
\hline \multirow[b]{2}{*}{$\begin{array}{l}\text { Case } \\
\text { No. }\end{array}$} & \multicolumn{3}{|c|}{ Serum DBA } & \multicolumn{3}{|c|}{ Serum TBA } \\
\hline & $\begin{array}{c}\text { Total } \\
(m g . \%)\end{array}$ & $\begin{array}{c}\% \text { as taurine } \\
\text { conjugate }\end{array}$ & $\begin{array}{c}\text { \% as glycine } \\
\text { conjugate }\end{array}$ & $\begin{array}{c}\text { Total } \\
(m g . \%)\end{array}$ & $\begin{array}{c}\% \text { as taurine } \\
\text { conjugate }\end{array}$ & $\begin{array}{c}\text { \% as glycine } \\
\text { conjugate }\end{array}$ \\
\hline $\begin{array}{l}28 \\
33 \\
13 \\
14 \\
15\end{array}$ & $\begin{array}{l}4.7 \\
2.1 \\
2.3\end{array}$ & $\begin{array}{l}\mathbf{0} \\
\mathbf{0} \\
\mathbf{0}\end{array}$ & $\begin{array}{l}18 \\
12 \\
35\end{array}$ & $\begin{array}{r}11.0 \\
3.5\end{array}$ & $\begin{array}{l}34 \\
38\end{array}$ & $\begin{array}{l}45 \\
42\end{array}$ \\
\hline
\end{tabular}

serum and urine of patients with hepatic disease, the following studies were performed:

a) State of conjugation. Preliminary studies, employing reverse phase partition chromatography of unhydrolyzed serum extracts, have been carried out to determine the state of conjugation of the serum bile acids (Table III). In 2 patients with biliary obstruction 34 to 38 per cent of the serum TBA was present as the taurine conjugate, and 42 to 45 per cent as the glycine conjugate. Three serum samples from patients with Laennec's cirrhosis were studied prior to hydrolysis. No taurine conjugated DBA was detectable. Twelve, 18 and 35 per cent, respectively, of the DBA in each of these samples exhibited the mobility of the glycine conjugate on the column. Further studies are in progress aimed at identifying the remaining fractions of the total DBA content of the serum in Laennec's cirrhosis.

b) Nature of the dihydroxy bile acid. The chenodeoxycholic acid (3, 7-dihydroxy cholanic acid) content of serum has been determined in several patients, by means of the specific colorimetric reaction of Isaksson (12) (Table IV). Chenodeoxycholic acid was found to constitute 56 to 100 per cent of the serum DBA in these patients.

Further characterization of the trihydroxy bile acid of serum has not yet been carried out. The ultraviolet absorption spectrum after heating with 65 per cent sulfuric acid, and the chromatographic behavior of this substance, are compatible with the 3,7,12-trihydroxycholanic acid structure of cholic acid, the only trihydroxy bile acid which has been identified in human bile.

c) Interaction of bile acids with serum proteins. Analysis of dialysates prepared from serum samples with a considerable bile acid content indicated that only a small proportion of the trihydroxy acid, and no detectable fraction of the dihydroxy bile acid, was diffusible (14). Since the dialysis membrane is freely permeable to the various bile acids, this observation suggested an extensive binding of the bile acids by serum proteins. In a series of dialysis-equilibrium experiments, reported in another paper (15), the binding activity was found to reside largely in the albumin fraction.

\section{DISCUSSION}

\section{Serum bile acid ratios in different types of hepatic disorder}

In patients with liver disease the nature of the hepatic disorder has a profound effect upon the relative amounts of tri- and dihydroxy bile acids present in the serum and upon their state of conjugation.

Figure 1 shows the ratios found between triand dihydroxy bile acids in patients with different types of hepatic disease. In Laennec's cirrhosis (Group II) the serum bile acid is almost entirely of the dihydroxy type, trihydroxy bile acid being found in small amounts in only 2 of 13 patients studied. In biliary obstruction (Group III), the concentration of the trihydroxy acid is from 1 to 4 times that of the dihydroxy bile acid. Serum bile acid ratios intermediate between those of Group II and Group III are found in the patients with hepatitis (Groups IV and V). No values are given for normal individuals since their serum levels are too low to measure by our methods. In normal human gall bladder bile, the ratio between the tri- and dihydroxy bile acids averages about 0.75 (16).

In obstructive liver disease, the serum bile acids are largely conjugated with taurine and glycine in roughly equivalent amounts (Table III) and in this respect resemble the bile acids found in nor- 
mal gall bladder bile. In patients with Laennec's cirrhosis, less than 35 per cent of the serum bile acid is conjugated and only the glycine conjugate is found.

A clear understanding of the pathologic mechanisms which underlie these findings must await more detailed knowledge of the metabolic origin of the cholanic acids than is available at present. Although Bloch, Berg, and Rittenberg (17), Siperstein and Chaikoff (18), and Bergström (19) have demonstrated that the bile acids are endproducts of the degradation of cholesterol, the details of the metabolic pathways involved are not yet defined. Certain observations, however, may help understand the reasons why the bile acids present in the serum of patients with biliary obstruction are different from those present in patients with Laennec's cirrhosis and why, in both diseases, the serum bile acids differ from those normally excreted in the bile. Bergström and Gloor $(20,21)$ have demonstrated the presence of an enzyme system in the liver cells of rats that converts deoxycholic (dihydroxy) acid into cholic (trihydroxy) acid, and of another enzyme that conjugates the free bile acids with glycine and taurine. This conjugating enzyme has been shown (21) to be present in normal human liver cells and it is probable that the hydroxylating enzyme also is present. If it is assumed that both of these enzyme systems are present and active in the liver cells of patients with biliary obstruction, the bile acids regurgitated into the serum should be completely conjugated. The percentage of trihydroxy acid in the serum of patients with biliary obstruction is considerably higher than in normal human bile (16); this difference might possibly arise from the longer retention of the bile acids within the body, thus permitting a more protracted action of the hydroxylating enzyme system.

The nature of the bile acids found in the serum of patients with Laennec's cirrhosis suggests a reduction in the activity of both the conjugating and hydroxylating enzyme systems in this disease. The failure to conjugate bile acids is paralleled by a similar failure to conjugate bilirubin. Schmid has reported (22) that bilirubin conjugated with glucuronic acid predominates in the serum of patients with regurgitation jaundice, while in retention jaundice most of the serum pigment is in
TABLE IV

Chenodeoxycholic acid content of serum

\begin{tabular}{|c|c|c|c|}
\hline $\begin{array}{l}\text { Case } \\
\text { No. }\end{array}$ & $\underset{\text { mb. \% }}{\text { Serum }}$ & $\begin{array}{l}\text { Serum } \\
\text { CDCA* } \\
\text { mg. \% }\end{array}$ & $\begin{array}{c}\text { CDCA } \\
\text { as \% of } \\
\text { DBA }\end{array}$ \\
\hline $\begin{array}{l}13 \\
15 \\
19 \\
25 \\
26 \\
31 \\
34 \\
36 \\
38\end{array}$ & $\begin{array}{l}5.0 \\
2.5 \\
1.0 \\
2.4 \\
3.4 \\
0.5 \\
6.4 \\
3.5 \\
3.9\end{array}$ & $\begin{array}{l}3.7 \\
1.6 \\
0.7 \\
2.4 \\
2.6 \\
0.4 \\
4.6 \\
2.0 \\
2.8\end{array}$ & $\begin{array}{r}74 \\
65 \\
70 \\
100 \\
77 \\
76 \\
72 \\
56 \\
73\end{array}$ \\
\hline
\end{tabular}

* CDCA, chenodeoxycholic acid.

the form of free bilirubin. The accumulation of unconjugated bile acids in the serum of these patients, in spite of unobstructed bile flow, suggests that the liver cells are unable to excrete unconjugated bile acids into the bile ducts. The presence of these acids in the serum of patients with Laennec's cirrhosis may be due largely to the failure of the conjugating enzyme system.

A variable degree of liver cell damage is undoubtedly present in most patients with obstructive jaundice and may perhaps be responsible for the variation in the ratio of tri- and dihydroxy bile acids found in these patients. The lowest ratios in this group were found in two patients (Nos. 27 and 30) with longstanding complete obstruction and marked impairment of liver cell function.

No information has been obtained in this study concerning the conjugation of serum bile acids in acute and chronic hepatitis. The ratios between the tri- and dihydroxy acids are intermediate between those found in Groups II and III. This suggests that cellular damage affecting the conjugating and hydroxylating enzyme systems is superimposed upon biliary obstruction in these patients.

\section{Serum bile acids in relation to other manifestations of hepatic dysfunction}

The serum bile acid concentration of the patients was compared with other laboratory findings indicative of the presence of hepatic disease (Table I).

No consistent relationship could be demonstrated between the level of bile acids and ab- 


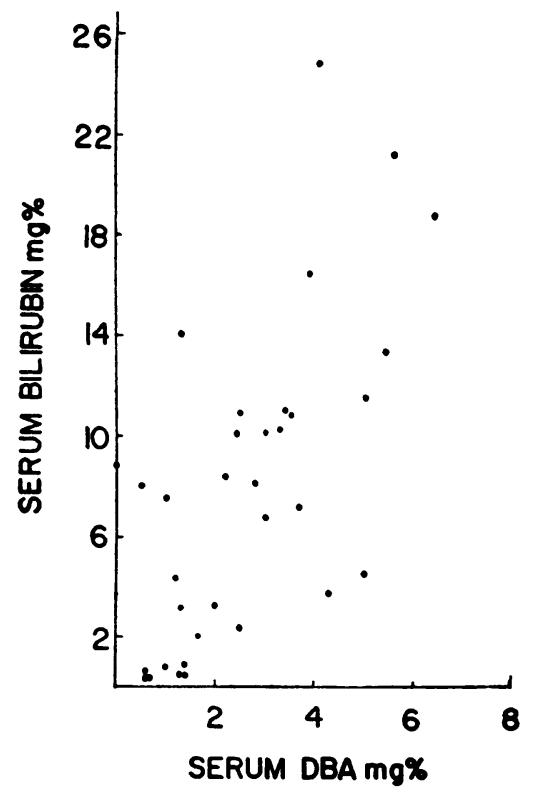

Fig. 2. Relationship of Serum Difydroxy Bile Acid Concentration to Serum Bilirubin Concentration in Patients with Hepatic Disease

normal values for cephalin flocculation or albuminglobulin ratio. The patients with appreciable serum levels of trihydroxy acids tended to have high values for serum alkaline phosphatase. These patients also exhibited high serum cholesterol levels. In all types of liver disease studied, high serum levels of bile acid tended to be associated with high values for serum bilirubin (Figure 2). In our series the correlation between these values was better for the patients with Laennec's cirrhosis, where practically all the serum bile acid was of the dihydroxy type, than for the patients with biliary obstruction.

In the patients with Laennec's cirrhosis, the serum DBA level did not reflect the over-all severity of the disease. Several patients with Laennec's cirrhosis advanced enough to produce neurological symptoms (Cases Nos. 11, 17), severe portal hypertension (Cases Nos. 16, 17, 20, 21) or marked hypoalbuminemia (Cases Nos. 12, 21, 22), exhibited relatively low serum DBA. Although serum DBA concentration showed little fluctuation in the individual cirrhotic patient (Table II), it was highly variable from one patient to another. Serum DBA concentration undoubtedly is determined by the interplay of several factors, including the rate of conversion of choles- terol to bile acid and the concentration of transporting plasma proteins.

\section{Excretion of bile acids in the urine}

Bile acids were found in the urine of all patients with obstructive jaundice having appreciable serum levels. Bile acids were not found in the urine of most patients with Laennec's cirrhosis. The presence of bile acid in the urine of two cirrhotic subjects (Cases Nos. 18 and 19) may be related to a moderate proteinuria which was present in both of these patients.

The mechanism of renal clearance of these substances appears to be glomerular filtration followed by extensive tubular reabsorption. At a serum concentration of $5 \mathrm{mg}$. per cent approximately 76 per cent of TBA and 95 per cent of DBA is bound to serum albumin. Only the unbound serum bile acid would be filtered by the glomeruli. On the basis of serum concentrations, binding constants (15) and urinary bile acid content, it was calculated that more than 95 per cent of the filtered bile acid was reabsorbed by the tubules in several patients with obstructive jaundice.

Preliminary observations have indicated that the bile acids in both the urine and serum of patients with obstructive jaundice are largely in conjugated form. In patients with Laennec's cirrhosis, only a small portion of the serum bile acid is conjugated. Differences in the state of conjugation of the bile acids may affect their renal tubular reabsorption. Further study of the nature of the bile acid conjugates in serum and urine will be necessary, in order to understand the differences in urinary excretion of bile acids in these patients.

\section{SUMMARY}

In normal subjects, bile acids were not detectable in the serum or urine. In 12 of 13 patients with Laennec's cirrhosis, 0.5 to $5.5 \mathrm{mg}$. per cent of dihydroxy bile acid (DBA) was present in the serum. In only two of these patients was trihydroxy bile acid (TBA) detectable ( 0.4 to $0.6 \mathrm{mg}$. per cent). Only a small proportion of the serum dihydroxy bile acid from patients with Laennec's cirrhosis was conjugated. Impaired activity of the conjugating and hydroxylating enzymes within 
the liver cells probably accounts for the serum bile acid findings in this group.

All of 10 patients with biliary obstruction were found to have an accumulation of both tri- and dihydroxy bile acids in the serum. The ratio of tri- to dihydroxy acid varied from 1 to 4 . In these patients the serum bile acids were largely conjugated with glycine and taurine, and probably accumulated in the blood as a result of regurgitation from the biliary passages.

The following correlations were observed between serum bile acids and the other findings of hepatic disease in these patients:

1) The serum TBA/DBA ratio indicated the relative intensities of biliary regurgitation and of hepato-cellular injury in the hepatic disorder.

2) Serum DBA concentration exhibited a correlation with serum bilirubin in both hepatocellular and regurgitative jaundice.

3) In patients with a component of biliary obstruction, the serum TBA concentration was proportional to the hypercholesterolemia.

Bile acids were regularly excreted in the urine by patients with obstructive jaundice, but were not detected in the majority of patients with Laennec's cirrhosis. Differences in the state of conjugation of the bile acids appear to affect the renal clearance of these substances.

\section{ACKNOWLEDGMENTS}

The authors are indebted to Dr. Ruth C. Harris of Babies' Hospital, N. Y., and Dr. Herbert J. Kayden of the N.Y.U. Research Service, Goldwater Memorial Hospital, for their helpful cooperation in this study.

\section{REFERENCES}

1. Perlzweig, W. A., and Barron, E. G., New colorimetric method for determination of bile acids in the blood. Proc. Soc. Exper. Biol. \& Med., 1926, 24, 233.

2. Irvin, J. L., Johnston, C. G., and Kopala, J., A photometric method for the determination of cholates in bile and blood. J. Biol. Chem., 1944, 153, 439.

3. Josephson, B., The determination of cholic acids in blood. Biochem. J., 1935, 29, 1519.

4. Aldrich, M., and Bledsoe, M. S., Studies in the metabolism of bile. I. A quantitative Pettenkofer test applicable to the determination of bile acids in the blood. J. Biol. Chem., 1928, 77, 519.
5. Sherlock, S., and Walshe, V., Blood cholates in normal subjects and in liver disease. Clin. Sc., 1948, 6, 223.

6. Snell, A. M., Clinical aspects of portal cirrhosis. Ann. Int. Med., 1931, 5, 338.

7. Mosbach, E. H., Zomzely, C., and Kendall, F. E., Separation of bile acids by column-partition chromatography. Arch. Biochem. \& Biophys., 1954, 48, 95.

8. Eriksson, S., and Sjövall, J., The absorption spectra of bile acids in sulfuric acid. Bile acids and steroids 31. Ark. Kemi, 1955, 8, 303.

9. Mosbach, E. H., Kalinsky, H. J., Halpern, E., and Kendall, F. E., Determination of deoxycholic and cholic acids in bile. Arch. Biochem. \& Biophys., 1954, 51, 402.

10. Rudman, D., and Kendall, F. E., Bile acid content of serum and urine in hepatic disease. Federation Proc., 1956, 15, 611.

11. Carey, J. B., Jr., The serum dihydroxy-trihydroxy bile acid ratio in liver and biliary tract disease. J. Clin. Invest., 1956, 35, 695.

12. Isaksson, B., A method for spectrophotometric determination of chenodesoxycholic acid in bile. Acta chem. Scandinav., 1954, 8, 889.

13. Norman, A., Separation of conjugated bile acids by partition chromatography. Bile acids and steroids 6. Acta chem. Scandinav., 1953, 7, 1413.

14. Rudman, D., Unpublished observations.

15. Rudman, D., and Kendall, F. E., Bile acid content of human serum. II. The binding of cholanic acids by human plasma proteins. J. Clin. Invest., 1957, 36, 538.

16. Isaksson, B., On the main cholanic acids of human bile from normal gallbladder and from gallbladder associated with cholesterol stones. Acta soc. med. Upsal., 1954, 59, 307.

17. Bloch, K., Berg, B. N., and Rittenberg, D., The biological conversion of cholesterol to cholic acid. J. Biol. Chem., 1943, 149, 511.

18. Siperstein, M. D., and Chaikoff, I. L., C ${ }^{14}$-cholesterol. III. Excretion of carbons 4 and 26 in feces, urine, and bile. J. Biol. Chem., 1952, 198, 93.

19. Bergström, S., The formation of bile acids from cholesterol in the rat. Proc. Roy. Physiographic Soc. Lund, 1952, 22, No. 16.

20. Bergström, S., and Gloor, U., Metabolism of bile acids in rat liver slices and homogenates. Bile acids and steroids 15 . Acta chem. Scandinav., 1954, 8, 1373.

21. Bergström, S., and Gloor, U., Metabolism of bile acids in liver slices and homogenates. Acta chem. Scandinav., 1954, 8, 1109.

22. Schmid, R., Direct-reacting bilirubin, bilirubin glucuronide, in serum, bile, and urine. Science, 1956, $124,76$. 